\title{
Asia and Climate Change: How It Will Play Out From the Bosporus to Djakarta
}

\author{
Jan-Erik Lane ${ }^{1}$ \\ ${ }^{1}$ Public Policy Institute, Belgrade, Serbia \\ Correspondence: Jan-Erik Lane, Public Policy Institute; 10 Charles Humbert, 1205 Geneva, 559 A, 3rd Floor, \\ Thuya Street, 9th Quarter, Yangon, Myanmar.
}

Received: March 10, 2017

Accepted: April 7, 2018

Online Published: April 9, 2018

doi:10.20849/ajsss.v3i2.358

URL: https://doi.org/10.20849/ajsss.v3i2.358

\begin{abstract}
Now that the measure of $\mathrm{CO} 2$ emissions has broken through 410 on the standard Keeling curve (Earth $\mathrm{CO} 2$ website), one may start drawing a scenario for climate change repercussions, here for the Asian continent. It pollutes most of all continents in terms of both greenhouse gases and many other pollutants. The threats to mankind comes in the form of sea level rise, fresh water shortage, less of potable water, shrinking of lakes and rivers, deoxygenation of oceans, less fish food and agriculture produce, energy shortages, omnipresent air conditioning, urban smog, water and sea pollution due to sewage and failures with landfills. Asia, hosting more than half of mankind, will suffer massively from global warming with millions of ecological refugees. The UN's program, the COP21 by the UNFCCC, cannot stop Asia from reaching Hawking irreversibility, because it entails too weak global governance that is cheatable. The promise of complete decarbonisation is an illusion.
\end{abstract}

Keywords: Asian CO2 emissions, decarbonisation in the COP21 plan, water, lakes, sea and oceans, victims of climate change

\section{Introduction}

Global average temperature will most probably be larger than the COP21 objective of plus 2 degrees Celsius. At what point on the temperature scale, we move into Hawking irreversibility is not known. But a rise beyond +4 degrees will have dramatic consequences for the ecology and human social systems.

A few days before the start of the UN global environment reunion COP23 (6-13 November 2017) in Bonn, the major study Climate Science Special Report: Fourth National Climate Assessment (USGCRP, 2017) https://assets.documentcloud.org/documents/4174364/Climate-Science-Special-Report-2017.pdf) was published in Washington. It examines the global warming problematic from the point of view of the US and the world, based upon years of research by a large group of US scholars. It presents an impressive list of climate change impacts upon the US territory and points decisively at human causes.

The Asian continent has taken over economic leadership from the Atlantic region. Now, roughly 60 per cent of global GDP comes from Asian countries, planning large increases in energy consumption up to 2040, resulting, most likely in massive $\mathrm{CO} 2$ emissions, globally.

\subsection{The Global CPR: COP21 as a Common Pool Regime}

All countries in the world have formed a common pool regime (CPR) to save the atmosphere from more GHGs, focusing only upon the $\mathrm{CO} 2 \mathrm{~s}$. The global decarbonisation plan includes:

i) Stall the rise if CO2s by 2020 (GOAL I);

ii) Decreasing the CO2s by $30-40 \%$ by 2030 (GOAL II) - relatively or absolutely?

iii) More or less full decarbonisation by around 2075 (GOAL III);

iv) Decentralised implementation under international oversight, financial support and technical assistance.

These are enormous goals, as only one country - Uruguay - is near GOAL I and GOAL II. Can they be implemented? Will the Asian miracle economies implement them or renege like the US? 


\section{Energy - Emissions}

The greenhouse gases (GHG) have a strong anthropogenic sources, being linked with socio-economic development or economic growth via the consumption of energy, especially the burning of fossil fuels, use of cement and emission of methane from land sinks, cows, microbes, fracking, etc. (Stern, 2007, 2015: Sachs, 2015). The UNFCCC has focused on halting CO2s and decreasing them in a gigantic decarbonisation policy globally in this century.

Energy demand in the coming decades will be enormous in Asia, as poor people try to change their situation and the new middle classes strive for even more of affluence as well as the newly rich billionaires and millionaires throw themselves into conspicuous consumption. Figure 1 shows the global connection between energy consumption and $\mathrm{CO} 2$ emissions.

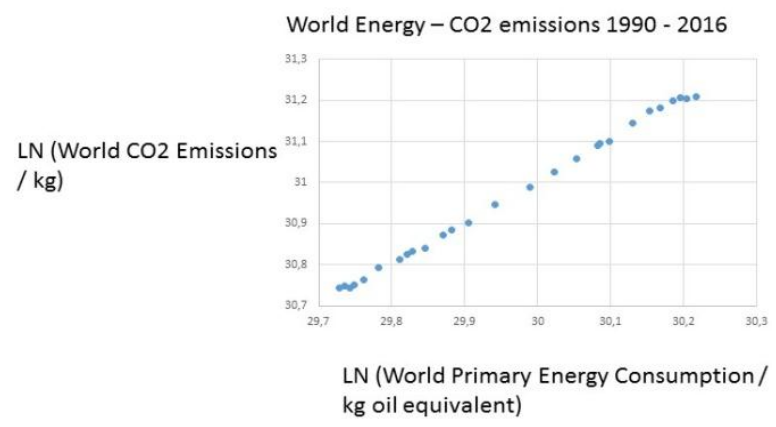

Figure 1. Energy and CO2: $s: y=1,01 x ; R^{2}=0,99$

Source: BP Statistical Review of World Energy 2017, http://www.bp.com/statisticalreview; Janssens-Maenhout, et al, 2017.

There is a one-to-one relationship over time between energy consumption and $\mathrm{CO} 2$ emissions. The Asian continent is the largest GHG emitter of all continents on Planet Earth.

Since 1970, global energy consumption has more than tripped. And the share of Asia has increased phenomenally. The Asian economic miracle started in Japan after the Second War, spread to the four miracles Taiwan, South Korea, Hong Kong and Singapore - only to include mainland China since1980, as well as further widening to all of South East Asia and South Asia plus Kazakhstan.

This economic revolution has made Asia the set of factories of the world, raising affluence and wealth as well as diminishing poverty. The cost is clear, as the Asian Development Bank states:

Southeast Asia is also becoming a larger contributor to global GHG emissions, with the fastest growth in carbon dioxide emissions in the world between Deforestation and land degradation have been driving most of the emissions to date. Given the region's vulnerability to climate change, curtailing global emissions growth should be a priority consideration, to which the region can make an important contribution. (ADB, 2015: Foreword)

The ADB has its solution to the energy-emission conundrum, namely carbon capture or sequestration. However, it is a costly and flawed technology for removing $\mathrm{CO} 2$ s. It will push the GHG problem to the Earth's crust, but it will not go ways. The same applies to the hope for an environmental Kuznets' curve.

\subsection{No Kuznets' Curve for CO2s}

Figure 2 shows that there is no Kuznets' curve (first rising, then descending) for $\mathrm{CO} 2$ : richer countries emit more $\mathrm{CO} 2$ than poor ones. International aviation is a very major source of $\mathrm{CO} 2$ emissions, and it is booming. 


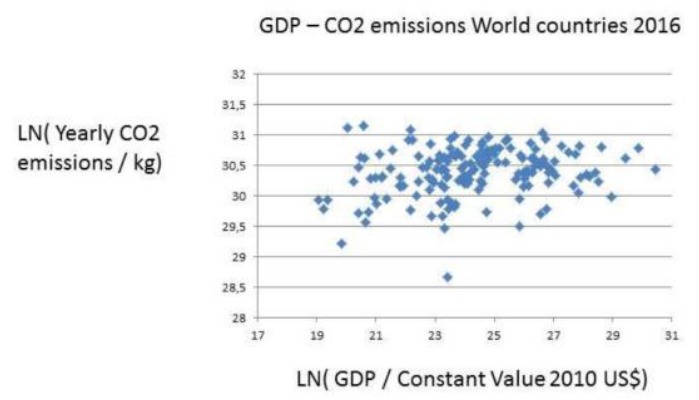

Figure 2. GDP-COP for all countries

\subsection{Asia's "Taking-off" And "Catching-up" Nations}

The CO2 emissions go with GDP growth, as the intermediate link is the ever expanding energy demand. Several Asian economies are now either mature, catch-up or taking-off economies (Rostow, 1960; Barro, 1991; Barro \& Sala-i-Martin, 1992, 1995). They want further economic expansion or socio-economic development, in order raise living standards.

Whether an Asian country like those in South Asia, Kazakhstan or Iran is "taking off" or if they have already come to the "catch-up" stage, like China and Turkey, they need ever more energy. In addition, the already mature economies in Asia, like Japan, South Korea and Singapore and the Gulf states, also project energy increases. Figure 3 has the global scene, with regional distributions.

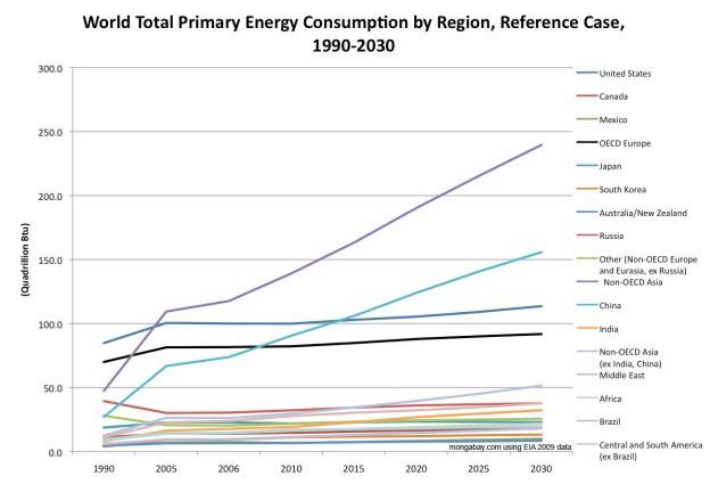

Figure 3. Energy 1990-2030

Source: https://rainforests.mongabay.com/energy/energy.html

Figure 3 informs about the increasing energy need in the world up to 2030 when the GOAL II in decarbonisation is to be fulfilled, according to COP21. Thus, we have decarbonisation as well as more energy demand. Only huge solar power parks can solve this contradiction. Figure 2 also shows the large role of Asian countries in this energy-emissions complex, whether it is a "taking off" nation like the Philippines or Vietnam, a "catching-up" nation like Thailand or Malaysia, or finally a mature economy like Japan.

\subsection{Water: Global Warming Negative Outcomes}

The process of climate change deteriorates the life situation for human beings through its impact upon fresh or potable water that is reduced. Water is a most important source of life and energy for humans.

\section{A. Fresh or Potable Water}

Access to fresh water is absolutely essential to man and woman on a daily basis. But in Asia the rivers and lakes are shrinking and the ground water levels are to be found at deeper and deeper levels. Moreover, the water retrieved thus is often polluted. One explanation is global warming, directly and indirectly. Potable water is the foundation of life and social systems. But fresh water is dwindling, as governments may have to turn to desalination plans, which though are very energy consuming. 
In Asia, fresh water used to be abundant in the huge rivers and lakes. But global warming means evaporation. Moreover, social developments have put an enormous pressure on water assets: population increase, dam construction, overfishing and pollution from sewage and waste. The great rivers are shrinking; Euphrates, Tigris, Indus, Brahmaputra, Ganges, Mekong, Yangtze, Yellow River, Irrawaddy Rive, The Salween, The Red River, etc. Several dams lack sufficient water, but more are planned or under construction.

Groundwater levels are also shrinking, as one is forced to drill deeper and irrigate more. Moreover, groundwater is found often to be polluted, salty or arsenic. Asian lakes are also shrinking and suffer degradation of water quality, like e.g. the huge Caspian Sea, or Inle Lake in Burma. Overfishing in the lakes is omnipresent.

Water scarcity is a lethal threat to local people in many Asian countries and it limits the usefulness of dams for electricity generation. Water quality deterioration will force ecology refuges to move to the urban areas. Drilling deeper requires energy, now often with solar pumps. But the risk of depletion is apparent. And building huge desalination plants will be extremely energy demanding. But water is basic necessity.

\section{B. Water Quality in the Oceans and Seas}

Many Asian countries have large fishing communities. Their income goes down due to overfishing and deoxygenation. This is another group of ecology refugees in the making besides poor peasants. The deterioration of the oceans is terms of oxygen is combined with enormous littering and oil spills. In addition, ocean water temperature is increasing, pushing fish stocks lower. Fish diminish in size by malnourishment and stocks are depleted by overfishing, having ripple effects on marine life.

\subsection{Cop Requirements and Emissions in a Few Asian Countries}

The COP Treaty makes several demands upon the signing states. First, they must make sure $\mathrm{CO} 2$ emissions begin to fall. Second, they must reduce CO2s by 25-40 per cent of the 2005 level up to 2030. Thirdly, they should arrive at more or less total decarbonisation by around 2075. Given the close association between CO2s and fossil fuel energy, the decarbonisation promises can only be fulfilled by reductions in the burning of coal, oil and natural gas. Below we look at the GDP and CO2 links in a few major Asian economies, from Bosporus to Djakarta. Are there plans to engage in strong decarbonisation?

\subsection{The Catch-up Strategy}

\subsubsection{Turkey}

Turkey has never been politically stable, neither today nor historically speaking. The Ottoman Empire was an example of oriental despotism, namely sultanismus. When the Young Turks set up modern Turkey, they failed to stabilize the country with a permanent constitution. The many constitutional changes reflect not only coup d'état, but also a weak tradition of the Rechtsstaat. Economically, things are entirely different, as Turkey is one of giants of the global economy, especially important with connections to the West and dominance in Turkestan.

Comparing the picture for Turkey with that of "catch-up" nations, one may state that Turkey has the typical GDP-GHG link, despite lots of hydro power. Strong economic development is combined with heavy emissions increase. Since the world organisations - the UN, WB and IMF - opt for more of economic growth, one must ask whether emissions growth really can be halted. Figure 4 supports this picture of Turkey as an energy consuming giant.

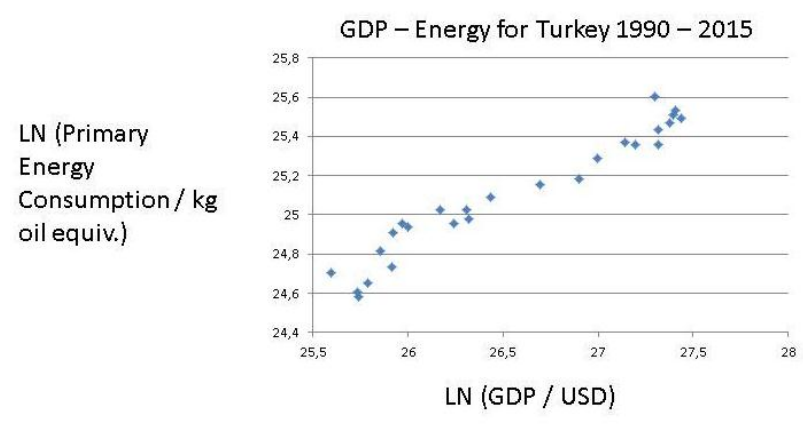

Figure 4. Turkey: energy-GDP link 
Strong economic development is combined with heavy energy-emissions increase. Oil and gas are imported from the East. Only hydro power is a large internal source of energy. Wind energy has become fashionable, but solar energy would be an ideal solution. Figure 5 displays the still heavy reliance of Turkey on fossil fuels, mostly imported. Decarbonisation according to the COP21 Treaty implies that Turkey must change drastically, as it now depend at $90 \%$ on fossil fuels.

\section{Primary Energy Consumption of Turkey}

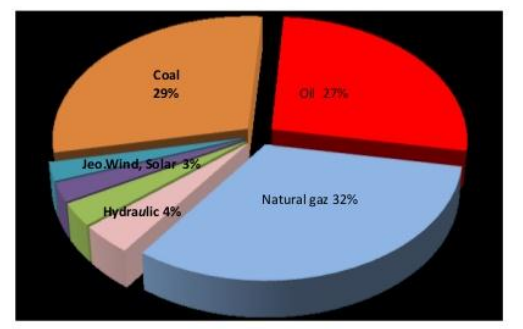

Figure 5. Energy mix in Turkey

Source: https://www.slideshare.net/omerfarukgurses/world-energy-outlook-2015-presentation

Turkey pursues the "catch-up" strategy in relation to the advanced capitalist countries (Barro, 1991, Barro and Sala-i-Martin, 1992, 1995). It is not very eagre to take on the burden for global decarbonisation, especially if it hurts their economic development. They would demand compensation from the promised Super Fund, as Turkey has now threatened to regene upon its COP21 promises.

\subsubsection{China}

It is alarming information that China, the biggest emitter of $\mathrm{CO} 2 \mathrm{~s}$, will not succeed to halt its curve for $\mathrm{CO} 2 \mathrm{~s}$. Instead, it counts upon some 3 per cent increases the nearest years - see Figure 6.

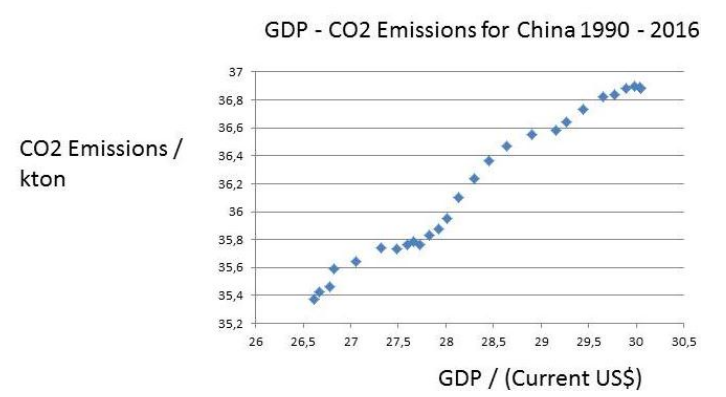

Figure 6. China: GDP and CO2s: $y=0,46 x, R^{2}=0,98$

China has officially declared that it intends to meet both COAL I, halting the increase in CO2s, and GOAL II, reducing $\mathrm{CO} 2$ s by some 30 per cent. But promises and intensions are one thing, real life developments another matter. All countries in this CPR can at any time renege, the US has already done.

China is well wall if huge pollution problem, making Beijing almost inhabitable some days. It invests heavily in both nuclear power and modern renewables. At the same time it keeps up its economic expansion in order to catch-up with the West:

i) Airports and own constructed aircraft;

ii) Biggest car market in the world'

iii) SUVs and ever larger engines; 
iv) The New Silk Road: infra structure expansion into Central Asia and the Middle East.

Air transportation adds much to $\mathrm{CO} 2$ emissions. Even if electrical cars are launched massively in China, one must ask where the electricity comes from. Coal?

Can China, or will China really comply with the COP21 objectives, listed above? Look at one standard coal projection - Figure 7 .

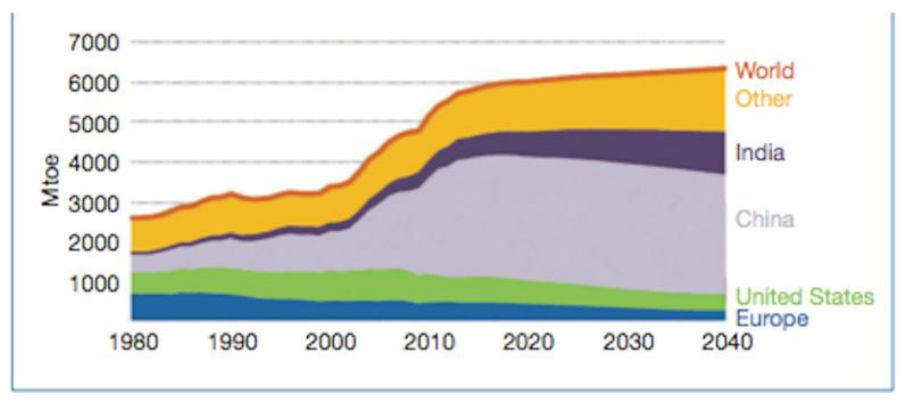

Figure 7. Global coal projections

Source: http://www.modernpowersystems.com/features/featureglobal-energy-steering-the-world-towards

-catastrophe -4814244/featureglobal-energy-steering-the-world-towards-catastrophe-4814244-2.html

\subsection{The Take-off Strategy}

\subsubsection{India}

Its Rostow take-off point in time would 1990, when Nehru's economic regime was abandoned for free market economics. Unleashing the dormant giant of India has led to enormous economic expansion and growth in Co2s - see Figure 8.

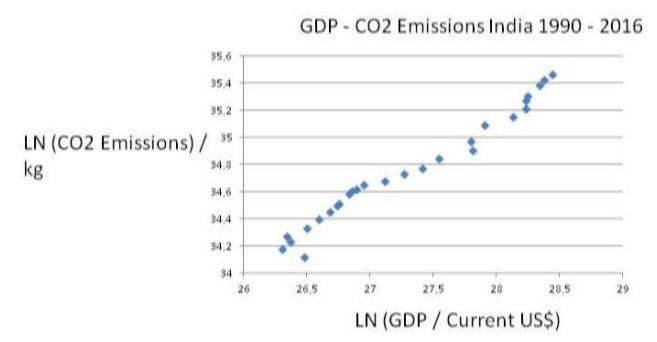

Figure 8. India: GDP and CO2

India takes the position that any reduction its economic growth due to the fulfillment of global decarbonisation must be compensated by the West. Moreover, the Super Fund should be employed for the energy transformation that is necessary for India to comply with GOAL I and GOAL 2.

As Ramesh (2015) explains, India cannot alone uplift its million poor without coal power. In addition, families in India rely much upon wood and charcoal - traditional renewables. The country is investing in nuclear power and modern renewables. However, its hydro power suffers from water scarcity - a positive feedback loop from climate change.

\subsubsection{Iran}

Iran has had several take-off points in time, but these occasions have been arrested by political reversals. Now, Iran prepares its strategy of catch-up, first with the Sunni Arab world and later with the West. Energy in Iran is all about fossil fuels: oil and gas. And the CO2s are high for Iran - Figure 9. 


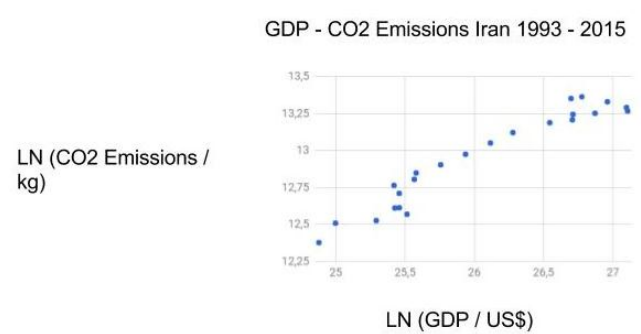

Figure 9. Iran

Iran will have to renege on COP21 objectives, unless receiving support from outside. The solution is apparent: solar power parks (Figure 10).

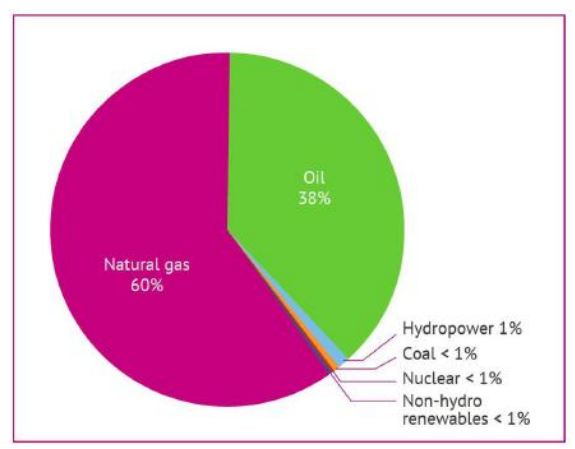

Figure 10. Energy mix in Iran 2014

Source: Energy Information administration, 2014

\subsubsection{Indonesia}

Indonesia has rapidly moved up as a major consumer of energy in the early 21 rst decade., refelcting growimh political stability and a strong effort to catch-up with the other Asian miracles. It has definitely passed its "take-off" stage, but interestingly its enormous consumption of energy has not been accompanied by high economic growth in most recent years (Figure 11).

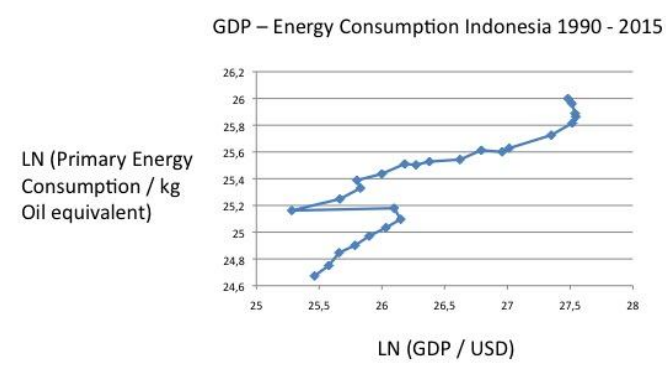

Figure 11. Indonesia GDP-energy: $y=0,46 x ; R^{2}=0,79$

The inward and upward sloping curve for Indonesia must be of concern to the elite in the country, because Indonesia has become a major contributor to $\mathrm{CO} 2$ emissions. If economic growth stalls due to inflation, then how to defend the enormous emissions? 
The bad CO2 emissions stem partly from the cutting and burning of rain forests and adjacent land on Kalimantan and Sumatra, which the government is to weak to control. The illegal fires affect other neighbouring countries but little is done to stop them. The search for more land for agriculture, especially soya planations, drives the externality. Emissions even outpace energy consumption. These rain forests are bound to disappear, as the Indonesian state does not have the capacity or even willingness to police these huge areas.

One may guess correctly that countries that try hard to "catch-up" will have increasing emissions. This was true of India. Giant Indonesia is now the fourth largest emitter of GHG:s in the world (Figure 12).

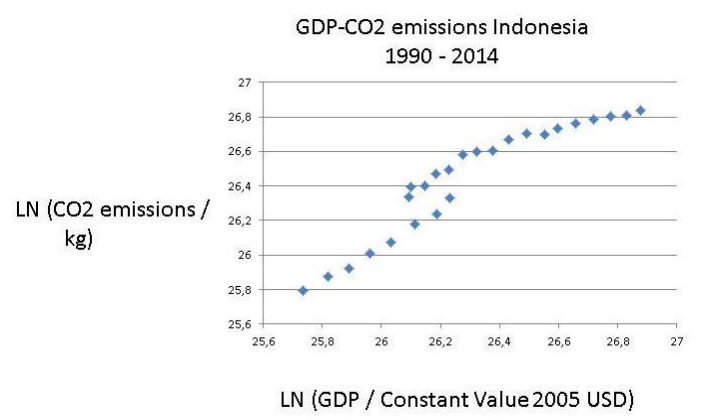

Figure 12. Indonesia: GDP-CO2 link: $\mathrm{y}=0,95 \mathrm{x}+1,58 ; \mathrm{R}^{2}=0,89$

Indonesia is a coming giant, both economically and sadly in terms of pollution. Figure 10 reminds of the upward trend for China and India. However, matters are even worse for Indonesia, as the burning of the rain forest augments the GHG emissions very much. Only 4 per cent comes from hydro power with 70 per cent from fossil fuels and the remaining 8 per cent from biomass, which alas also pollutes (Figure 13).

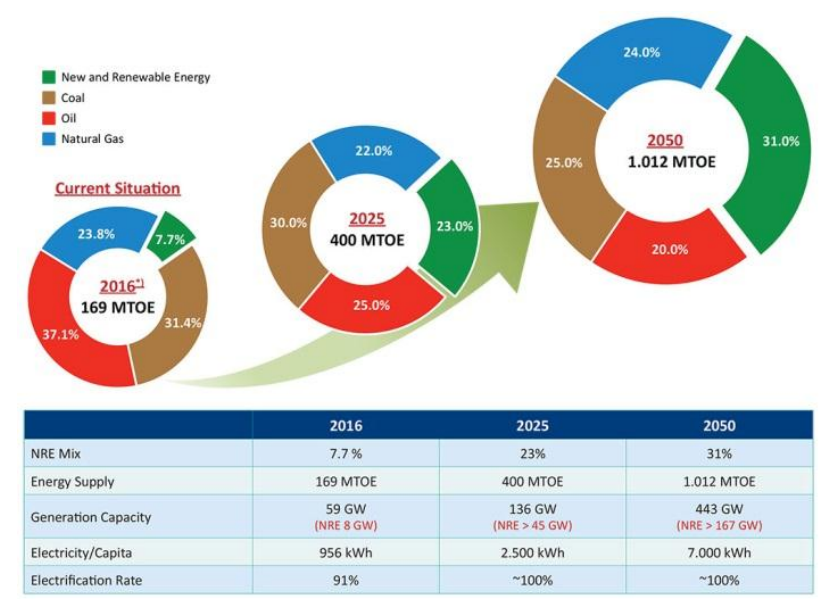

Figure 13. Indonesia's energy mix

Source: http://there4i.org/conference/page/AboutIndonesiaRE

Here, we see the weakness of GOAL II in the COP21 project: absolute or relative reduction of CO2s? Indonesia plans an enormous increase in energy supply with sizeable renewables and hydro power, but the burning of fossil fuel will increase absolutely, due to the giant energy supply growth. Moreover, also lakes in Indonesia are shrinking and increasingly polluted.

\subsubsection{Kazakhstan: Oil and Gas}

Here, we have a nation very much occupied with the catch-up strategy, as its exit from the Soviet Union worked like a "take-off" stage. It wants to copy the Asian miracles, moving to affluence in a few decades, using its immense fossil energy resources (Figure 14). But this picture of over $90 \%$ fossil fuels is very far from the obligations under the COP21 Treaty. 


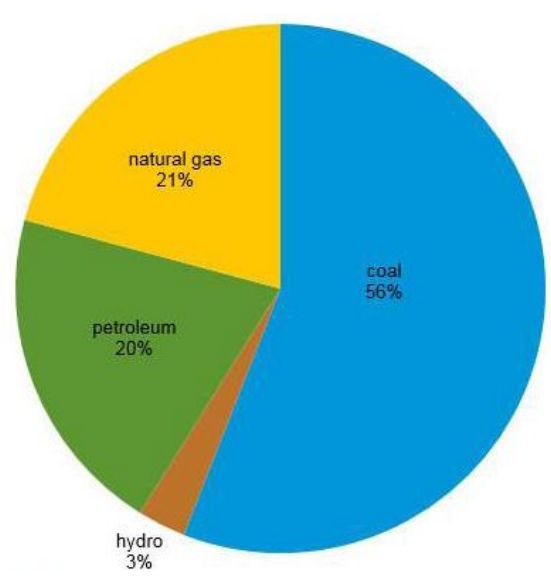

Figure 14. Energy mix

Source: U.S. energy information administration

Kazakhstan's energy consumption leads to enormous emissions. The stunning economic development, including the great project of a modern Silk Roan from China to Turkey through Kazakhstan implies that the CO21 goals cannot be accomplished here. Catch-up strategy and huge infrastructure trump climate change. Countries with no hydro power often display increasing trends for emissions. Kazahkstan employs its vast fossil fuel resources for energy consumpton besides exporting a lot. But it has to start energy transformation towards renewables

\subsection{Asian Mature Economies}

South Korea is today a member of the club of First Advanced economies, the OECD. From dismal poverty, it has pursued a spectacularly successful catch-up strategy, making it a global leader in technology and car production. The transformation is all the remarkable, as the country possess few internal power resources. Thus, it has relied upon imported fossil fuels, with the result in Figure 15, huge $\mathrm{CO} 2$ emissions.

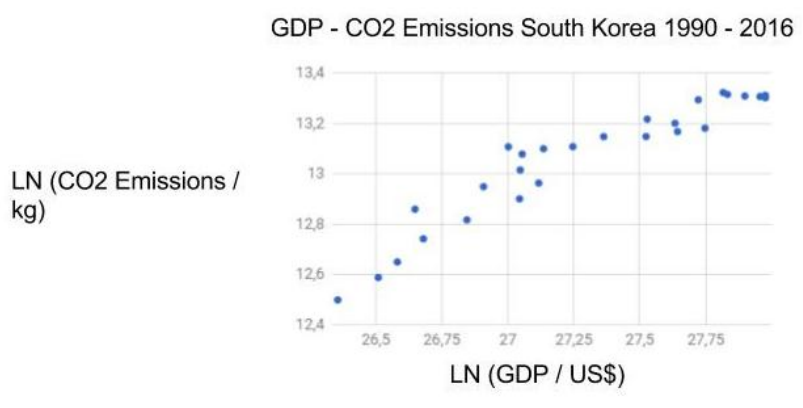

Figure 15. South Korea

To come to grips with its enormous GHG emissions, South Korea has attempted to reduce its coal dependency. Thus, it engaged upon a most ambition nuclear program, as its force is the largest power source in the world. South Korea with its advanced technology can build new and better as well as safer atomic power plants, also constructing them abroad. But the new president hesitates about nuclear power, like the European governments, and has launched a new energy strategy based massively upon natural gas (LNG), imported mainly from Australia and Indonesia. But it will still result in $\mathrm{CO} 2$ emissions higher than GOAL II in CO21. And international maritime transportation is a major source of $\mathrm{CO} 2 \mathrm{~s}$.

The LNG option may also appear attractive to Japan, hesitant about the use of atomic power. The Fukushima atomic power plant disaster changed energy policy in Japan, with an almost \%-stop of nuclear plants. But what use in Japan? See a plan in Figure 16. 


\section{JAPAN'S ENERGY MIX BY 2030}

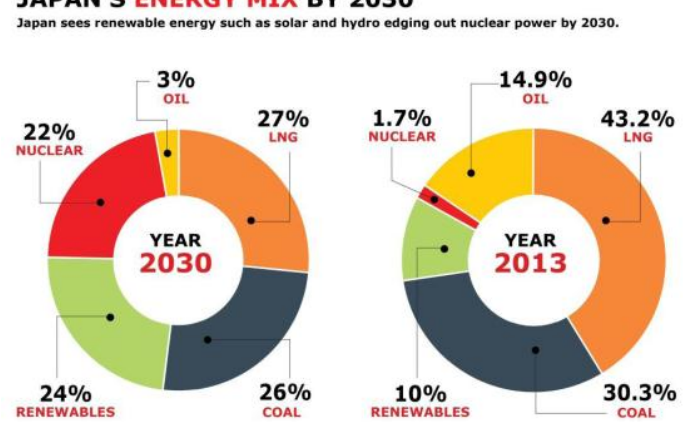

Figure 16. Japan's future energy mix

Source: Ministry of economy, trade and industry, Japan, 2015

This plan relies upon a big return to nuclear power, as there are safer models now. But is it politically realistic? If not, Japan must increase imports of fossil fuels, and renege upon COP21.

\subsection{CO2s and Methane}

There are several greenhouse gases, but the two biggest are the CO2s and methane. The UNFCCC has concentrated upon halting and reducing carbon dioxide, but now we are about to face a methane threat. Figure 17 shows how $\mathrm{CO} 2$ emissions may raise temperature to 4-5 degrees - the Hawking irreversibility point:

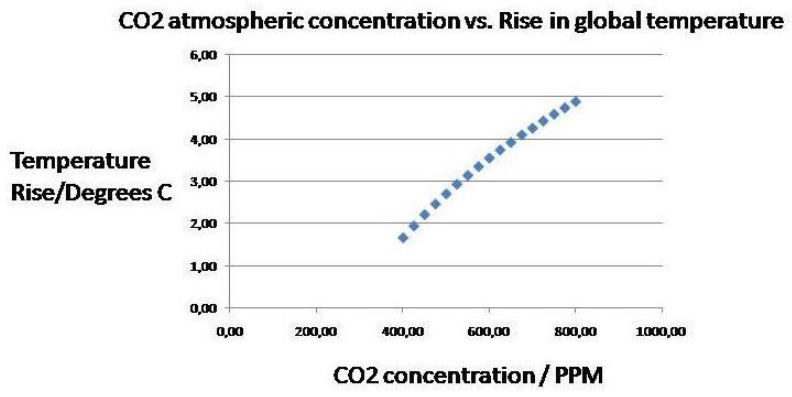

Figure 17. CO2s and temperature rise in Celsius

The most important contribution to the recent rise of methane concentration is mainly due to the increase in activity by microbes. This study suggests the positive feedback of the chemical increase of activity of microbes is starting now, yielding a quasi-exponential curve in the near future, or at least a steeper curve.

Any decrease in methane concentration is very unlikely, as the main sources (in decreasing importance order) generally increase:

a) Agriculture emissions increase with the increase of population, the increase in meat diet in developing countries and the temperature increasing the metabolism of microbes in rice agriculture.

b) Wetlands emissions will not decrease with temperature for many years, increase in landfills;

c) Fossil fuel production and use will not diminish yet, and is underestimated by industry, fracking (Fred Pearce, http://e360.yale.edu/features/methane_riddle_what_is_causing_the_rise_in emissions).

d) Biomass burning will not diminish, as the primary forest diminishes in the tropics, leading also to a decrease in animal, vegetal and cultural (Indigenous People) diversities and an increase in biosphere entropy.

e) Other natural emissions

A projection for methane emissions is done in Figure 18. 


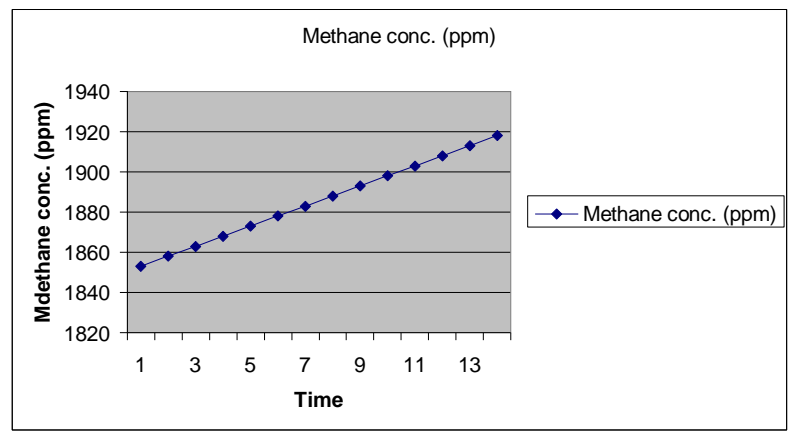

Figure 18. Projected increase in methane (Dieterlen)

\subsection{Decarbonisation Strategies}

The UNFCCC suggests a decentralized management strategy for decarbonisation. Reflecting the enormous differences in available energy resources in the member states of COP21 Treaty, each government must develop a strategy for achieving Goal I, Goal II and Goal III. The COP may wish to concentrate upon the following measures start credible decarbonisation:

1) Phasing out coal power plants; convincing a few countries like India and Australia not to build new ones;

2) Replace wood coal with natural gas - small or large scale, stopping deforestation and the use of charcoal in households in poor nations;

3) Turn some countries away from massive dam constructions towards solar power parks, like Brazil and India, as the environmental damages are too big;

4) Help some countries maintain their huge forests: Brazil, Indonesia, Malaysia, Russia, Kongo Basin, India, etc.;

5) Abstain from expensive and unsafe carbon sequestration techniques in favour of electricity: solar power and electrical vehicles.

6) The promise of financial support - Super Fund -has to be clarified about both funding and budgeting. A management structure has to be introduced for oversight of the entire decarbonisation process. As the emission of methane increases, the reduction of $\mathrm{CO} 2 \mathrm{~s}$ is all the more important, if irreversibility is to be avoided with a margin.

7) The resort to atomic power plants is highly contested. Nuclear power gets safer and safer, but the problem of storing the used uranium has no solution. If global warming becomes really bad, all these radioactive materials could be released back in our social systems and nature. Some countries expand atomic energy, whereas others dismantle it.

8) Massive construction of solar power and wind power plants in all countries, as well as stimulate small scale solar power; Solar power parks: How many would be needed to replace the energy cut in fossil fuels and maintain the same energy amount, for a few selected countries with big $\mathrm{CO} 2$ emissions?

9) Table 1 has an answer.

Table 1. Number of Ouarzazate plants necessary in 2030 for COP21's GOAL II: (Note: Average of 250 - 300 days of sunshine used for all entries except Australia, Indonesia, and Mexico, where 300 - 350 was used)

\begin{tabular}{llll}
\hline Nation & $\begin{array}{l}\text { Co2 reduction pledge } / \\
\text { \% of 2005 emissions }\end{array}$ & $\begin{array}{l}\text { Number of gigantic solar } \\
\text { plants needed (Ouarzazate) }\end{array}$ & $\begin{array}{l}\text { Gigantic plants needed } \\
\text { for 40 \% reduction }\end{array}$ \\
\hline China & none $^{\mathrm{i}}$ & 0 & 3300 \\
\hline India & none $^{\mathrm{ii}}$ & 0 & 600 \\
\hline Japan & 26 & 460 & 700 \\
\hline
\end{tabular}




\begin{tabular}{|c|c|c|c|}
\hline South Korea & 37 & 260 & 280 \\
\hline Philippines & 70 & 70 & 40 \\
\hline Turkey & 21 & 60 & 120 \\
\hline Indonesia & 29 & 120 & 170 \\
\hline Saudi Arabia & none $e^{\mathrm{ii}}$ & 0 & 150 \\
\hline Iran & $4-12^{\mathrm{iv}}$ & 22 & 220 \\
\hline Kazakhstan & none $\mathrm{e}^{\mathrm{ii}}$ & 0 & 100 \\
\hline Turkey & 21 & 60 & 120 \\
\hline Thailand & $20-25^{\text {iv }}$ & 50 & 110 \\
\hline Malaysia & none $e^{\mathrm{ii}}$ & 0 & 80 \\
\hline Pakistan & none $\mathrm{e}^{\mathrm{ii}}$ & 0 & 60 \\
\hline Bangladesh & 3,45 & 2 & 18 \\
\hline Australia & $26-28$ & 130 & 190 \\
\hline World & N/A & N/A & 16000 \\
\hline
\end{tabular}

Notes: i)The United States has pulled out of the deal; ii) No absolute target; iii) Pledge is above current level, no reduction; iv) Upper limit dependent on receiving financial support; v) EU joint pledge of $40 \%$ compared to 1990.

\section{Conclusion}

The Asian continent has become the leader of the global market economy, demanding enormous amounts of energy, which results in Asia having more than 50\% of global $\mathrm{CO} 2$. But Asia does not possess a highly sustainable environment to be able to handle the outcomes of climate change. For instance, rivers and lakes are shrinking, glaciers are melting, creatures in oceans and seas suffer from increase deoxygenation and asphyxia. Sea level rise is observable in island states and Bangladesh e.g. Hoter temperature on land and in sea hit both agriculture and fishing, meaning food in Asia. A stream of environmental refugees is foreseeable.

Despite the adherence to the COP21 Agreement and the forthcoming of several local innovations in energy supply, the reliance in Asia upon fossil fuel is massive. And it will hardly go down much, because Asian nations are committed to the "take-off" and "catch up" strategies. We may have to wait too long before Asian nations start real decarbonisation (Stern, 207, 2015). Only water scarcity and degradation will trigger a fundamental change.

\section{References}

Asian Development Bank. (2015). Southeast Asia and the economics of global climate stabilization. Mandaluyong City, Philippines: Asian Development Bank.

Barro, R. J. (1991) Economic Growth in a Cross Section of Countries. The Quarterly Journal of Economics, 106(2), 407-443. https://doi.org/10.2307/2937943

Barro, R. J., \& Xavier, X. Sala-i-Martin. (1992). Convergence. Journal of Political Economy, 100(2), 223-251. https://doi.org/10.1086/261816

Barro, R. J., \& Xavier,X. Sala-i-Martin. (1995). Economic Growth. McGrow Hill.

Climate Science Special Report: Fourth National Climate Assessment (USGCRP, 2017). Retrieved from https://assets.documentcloud.org/documents/4174364/Climate-Science-Special-Report-2017.pdf) 
Myhre, G., Highwood, E. J., Shine, K. P., \& Stordal, F. (1998). New estimates of radiative forcing due to well mixed greenhouse gases. Geophysics Research Letters, 25(14), 2715-2718. https://doi.org/10.1029/98GL01908

Ramesh, J. (2015). Green Signals: Ecology, Growth and Democracy in India. Oxford : Oxford University Press. https://doi.org/10.1093/acprof:oso/9780199457526.001.0001

Rostow, W. W. (1960). The Stages of Economic Growth: A Non-Communist Manifesto. Cambridge: Cambridge University Press.

Sachs, J. D. (2015). The Age of Sustainable Development. New York: Columbia University Press. https://doi.org/10.7312/sach17314

Stern, N. (2007). The Economics of Climate Change. Oxford: OUP.

Stern, N. (2015). What are we waiting for? Cambridge, MA: MIT Press.

\section{Solar power sources:}

CO2 Emission Reduction With Solar: http://www.solarmango.com/in/tools/solar-carbon-emission-reduction

EDGAR. European Commission, Joint Research Centre (JRC)/PBL Netherlands Environmental Assessment Agency. Emission Database for Global Atmospheric Research (EDGAR), release version 4.3.2. http://edgar.jrc.ec.europe.eu, 2016 forthcoming

Janssens-Maenhout, G., Crippa, M., Guizzardi, D., Muntean, M., Schaaf, E., Olivier, J. G. J., ... Schure, K.M.: Fossil CO2 and GHG emissions of all world countries, EUR 28766 EN,Publications Office of the European Union, Luxembourg, 2017, ISBN 978-92-79-73207-2, doi:10.2760/709792, JRC107877. World Bank Data Indicators, http://data.worldbank.org

Paris 2015: Tracking country climate pledges. Carbon Brief. Retrieved from https://www.carbonbrief.org/paris-2015-tracking-country-climate-pledges

\section{GDP sources:}

OECD National Accounts data files

World Bank national accounts data - data.worldbank.org

\section{GHG and energy sources:}

BP Energy Outlook 2016.

British Petroleum Statistical Review of World Energy 2016

Energy Information Administration. Washington, DC.

EU Emissions Database for Global Research EDGAR: http://edgar.jrc.ec.europa.eu/

EU Joint Research Centre Emission Database for Global Atmospheric Research http://edgar.jrc.ec.europa.eu/overview.php

International Energy Agency. Paris.

UN Framework Convention Change: http://unfccc.int/ghg_data/ghg_data_unfccc/time_series_annex_i/items/3814.php

World Bank Data Indicators, data.worldbank.org

World Resources Institute CAIT Climate Data Explorer - cait.wri.org

\section{Copyrights}

Copyright for this article is retained by the author(s), with first publication rights granted to the journal.

This is an open-access article distributed under the terms and conditions of the Creative Commons Attribution license (http://creativecommons.org/licenses/by/4.0/). 